\title{
Nitric Oxide Inhibits NF-kB-mediated Survival Signaling: Possible Role in Overcoming TRAIL Resistance
}

\author{
JOSEPH A. BAUER ${ }^{1}$, JOSEPH A. LUPICA ${ }^{2}$, JOSEPH A. DIDONATO ${ }^{3}$ and DANIEL J. LINDNER ${ }^{4}$ \\ ${ }^{1}$ Nitric Oxide Services, LLC, St. John Paul II Center for Science Innovation, North Canton, OH, U.S.A.; \\ ${ }^{2}$ Department of Math \& Sciences, Walsh University, North Canton, OH, U.S.A.; \\ ${ }^{3}$ Department of Cardiovascular \& Metabolic Sciences, Lerner Research Institute, \\ Cleveland Clinic Foundation, Cleveland, OH, U.S.A.; \\ ${ }^{4}$ Translational Hematology Oncology Research (THOR), Taussig Cancer Center, \\ Cleveland Clinic Foundation, Cleveland, OH, U.S.A.
}

\begin{abstract}
Background/Aim: Chemoresistance is a major consequence of multicycle chemotherapy and can be attributed to constitutive activation of pro-survival signaling pathways. Nitric oxide is a ubiquitous signaling molecule which has been shown to inhibit several pathways involved with survival signaling in cancer cells. We have previously demonstrated the anti-tumor activity of a nitric oxide-donor, nitrosylcobalamin $(\mathrm{NO}-\mathrm{Cbl})$, mediated by increased expression of tumor necrosis factor-related apoptosis-inducing ligand (Apo2L/TRAIL) and its receptors in human tumors. We also demonstrated that a functional Apo2L/TRAIL receptor is necessary for the induction of cell death by NO-Cbl and the Apo2L/TRAIL death receptor DR4 (TRAIL RI) is S-nitrosylated. The aim of the study was to examine the effects of nitric oxide (NO) on nuclear factor kappa $B(N F-k B)$ and determine whether nitric oxide could sensitize drug-resistant melanomas to Apo2L/TRAIL via inhibition of NF${ }_{k} B$ or inhibitor kappa B kinase (IKK). Materials and Methods: Antiproliferative effects of $\mathrm{NO}-\mathrm{Cbl}$ and Apo2L/TRAIL were assessed in malignant melanomas and non-tumorigenic melanocyte and fibroblast cell lines. Athymic nude mice bearing human melanoma A375 xenografts were treated with $\mathrm{NO}-\mathrm{Cbl}$ and Apo2L/TRAIL. Apoptosis was measured by the TUNEL assay. The activation status of $N F-k B$ was established by assaying luciferase reporter activity, the phosphorylation status
\end{abstract}

This article is freely accessible online.

Correspondence to: Daniel J. Lindner, MD, Ph.D., Cleveland Clinic, 9500 Euclid Ave, Cleveland, OH 44195, U.S.A. Tel: +1 2164450548, e-mail: lindned@ccf.org, and Joseph A. DiDonato, Assistant Professor, Department of Cardiovascular \& Metabolic Sciences, Lerner Research Institute, Cleveland Clinic Foundation, Cleveland, OH 44106, U.S.A. Tel: +1 2164448178, e-mail: didonaj@ccf.org

Key Words: Apo2L/TRAIL, nitric oxide, nuclear factor kappa B, inhibitor kappa B kinase, apoptosis. of IkB $\alpha$, and in vitro IKK activity. Results: $\mathrm{NO}-\mathrm{Cbl}$ sensitized Apo2L/TRAIL-resistant melanoma cell lines to growth inhibition by Apo2L/TRAIL, but had minimal effect on normal cell lines. NO-Cbl and Apo2L/TRAIL exerted synergistic anti-tumor activity against A375 xenografts. NO-Cbl suppressed Apo2L/TRAIL-and TNF- $\alpha$-mediated activation of a transfected $\mathrm{NF}-\mathrm{kB}$-driven luciferase reporter. $\mathrm{NO}-\mathrm{Cbl}$ inhibited IKK activation, characterized by decreased phosphorylation of IkBa. Conclusion: NO-Cbl treatment rendered Apo2L/TRAIL-resistant malignancies sensitive to the anti-tumor effects of Apo2L/TRAIL in vitro and in vivo. The use of nitric oxide to inhibit $N F-k B$ and potentiate the effects of chemotherapeutic agents, such as Apo2L/TRAIL, represents a promising anti-cancer combination based on recent clinical investigations of anti-TRAIL antibodies for cancer treatment strategies.

Apoptosis is the rigorously controlled process of programmed cell death. Current trends in cancer drug design focus on selective targeting to activate the apoptotic signaling pathways within tumors while sparing normal cells (1). The in vitro tumor-specific properties of tumor necrosis factor-related apoptosis-inducing ligand (Apo2L/TRAIL) have been investigated since the 1990s (2-5). Apo2L/TRAIL has been evaluated in vitro as an anti-cancer agent alone and in combination with other agents (6-10) including ionizing radiation (11-13) which has helped elucidate its mechanism of action. Recently, wild-type p53 expression has been associated with increased TRAIL-receptor mediated apoptosis but also has been shown to activate survival signaling (14). Additionally, Apo2L/TRAIL can initiate apoptosis in cells that overexpress the survival factors $\mathrm{Bcl}-2$ and $\mathrm{Bcl}-\mathrm{X}_{\mathrm{L}}$, and may represent a treatment strategy for tumors that have acquired resistance to chemotherapeutic drugs (15).

Apo2L/TRAIL binds to two TRAIL receptors TRAIL-R1 (DR4) and TRAIL-R2 (DR5) that mediate apoptotic signaling (16) which have been shown to be present on cancer cells and 
not normal cells. Studies have shown that Map kinase Activating death domain containing protein (MADD) is a pro-survival mediator of TRAIL signaling and a MADD knockout model demonstrated sensitivity to TRAIL in aplastic thyroid cancer (17). In addition, the inhibitor of TRAIL-mediated apoptosis cFLIP has been identified as a major factor in the resistance of ER-positive breast cancer patients (18). Oncogenes such as RAS, MYC and HER2 have been shown to sensitize cancer cells to TRAIL-mediated cell death (19). Inhibition of XIAP has also shown increased antitumor activity of TRAIL in leukemia cells (20). TRAIL receptor agonists are being evaluated clinically, however, resistance is a major factor involved in their efficacy $(20,21)$ which can be attributed to the dual nature of apoptosis and protection inherent with TRAIL signaling (16).

Nitric oxide is a key signaling molecule involved in almost every aspect of human physiology as well as pathology. The dichotomous nature of nitric oxide is determined based on 3 principle factors, 1) site of NO production/delivery 2) NO concentration, and 3) duration of NO production. NO produced in vivo has been shown to prevent tumorigenesis $(22,23)$ and numerous studies have shown the anti-tumor effects of nitric oxide donor compounds in cancer therapy (24-27).

Nitrosylcobalamin (NO-Cbl), is an analogue of vitamin B12 (cobalamin, Cbl) coordinated with nitric oxide (NO) as a ligand (28). Similar to Apo2L/TRAIL, the CD320 receptor specific for $\mathrm{NO}-\mathrm{Cbl}$, is overexpressed on cancer cells compared to normal cells $(29,30)$. Accordingly, we pursued a target for possible nitrosylation on TRAIL R1 and identified the Cys-336 residue of the Apo2L/TRAIL death receptor TRAIL R1 as a target for S-nitrosylation by NO-Cbl. We assessed wild-type DR4 C336 compared to mutant DR4 C336A which did not result in S-nitrosylation by NO-Cbl and was more resistant to growth inhibition by NO-Cbl (31).

Several studies have shown that TRAIL induces apoptosis in cancer cells but simultaneously activates NF-kB (32-36). Additionally, we showed that several chemotherapeutic agents activate NF-kB survival signaling (37) and agents, including nitric oxide-donors, that inhibit NF-kB can potentiate anti-tumor activity (37-39). NO has been to shown to sensitize TRAILresistant tumors to TRAIL via inhibition of NF-kB $(40,41)$.

In this study we pre-treated cells with the nitric oxide donor, NO-Cbl, to inhibit NF-kB activity and enhance the apoptotic signal of Apo2L/TRAIL. Our specific aims were to 1) measure the anti-tumor effects of NO-Cbl and Apo2L/TRAIL in Apo2L/TRAIL-resistant cell lines, and to 2) determine the mechanism by which NO-Cbl inhibits NF-kB activation.

\section{Materials and Methods}

Synthesis of nitrosylcobalamin. Nitrosylcobalamin was synthesized as previously described $(28,42)$. Hydroxocobalamin (vitamin B12a) acetate (George Uhe Company, Paramus, NJ, USA) was dissolved in dichloromethane (Burdick and Jackson, Muskegon, MI, USA) and exposed to CP grade NO gas (Praxair, Danbury, CT, USA). The reaction proceeds in a closed system within a high-pressure gas cylinder (Midwest Process Controls, Avon Lake, OH, USA). The system was nitrogen-purged daily and evacuated prior to NO exposure. The NO gas was scrubbed prior to entering the system using a stainless-steel cylinder (Midwest Process Controls) containing $\mathrm{NaOH}$ pellets. The solid NO-Cbl product was collected following rotary evaporation of the solvent and stored at $-80^{\circ} \mathrm{C}$ prior to use.

Cell culture and cytokine treatment. Human melanoma tumor cell lines, WM9 and WM3211 (Wistar Institute, Philadelphia, PA, USA), and A375 (ATCC, Manassas, VA, USA) were grown in Dulbecco's modified Eagle medium (DMEM; Life Technologies Inc., Rockville, MD, USA) supplemented with heat-inactivated $10 \%$ fetal bovine serum (FBS; HyClone, Logan, UT, USA) and 1\% AntibioticAntimycotic (GIBCO BRL, Invitrogen, Carlsbad, CA, USA). Cells were maintained in $5 \% \mathrm{CO}_{2}$ at $37^{\circ} \mathrm{C}$ in a humidified tissue culture incubator. Primary non-tumorigenic melanoma cell lines (DMN-1 and $\mathrm{CMN}-1$, A. Gudkov, CCF, Cleveland, OH, USA), and human foreskin fibroblasts (HFF; $\mathrm{CCF}$, Cleveland, $\mathrm{OH}$, USA) were cultured in DMEM-F12 medium supplemented with 10\% FBS. Cells were confirmed as mycoplasma free.

All experiments were performed using trimeric recombinant human Apo2L/TRAIL (43) (Genentech Inc, San Francisco, CA, USA) and were independently confirmed using recombinant Apo2L/TRAIL from another source (Peprotech Inc, Rocky Hill, NJ, USA). Apo2L/TRAIL (Genentech), consisted of $>99 \%$ trimeric protein with $\mathrm{Zn}^{+2}$, which is necessary for optimal biologic activity of Apo2L/TRAIL (43).

Sulforhodamine B cell growth assay. Cells were harvested with $0.5 \%$ trypsin/0.53 mM EDTA, washed with PBS and resuspended in media containing $10 \%$ FBS. Cells were plated in 96-well plates in $0.2-\mathrm{ml}$ aliquots containing $10^{4}$ cells. Cells adhered to the plate for $4 \mathrm{~h}$ and then NO-Cbl was added in different dilutions $(25,50$ and $100 \mu \mathrm{M})$ to the assay plate. Replicates of four were performed for each treatment. After $16 \mathrm{~h}$, recombinant human Apo2L/TRAIL was added at different concentrations $(25-100 \mathrm{ng} / \mathrm{ml})$. Growth was monitored by the sulforhodamine B (SRB; Sigma Chemical, St. Louis, MO, USA) colorimetric assay (44). After $40 \mathrm{~h}$ growth, the medium was removed, and the cells were fixed with $10 \%$ trichloroacetic acid and stained with SRB. Bound dye was eluted from the cells with $10 \mathrm{mM}$ Tris- $\mathrm{HCl}(\mathrm{pH}$ 10.5) and absorbance was measured at $570 \mathrm{~nm}$ using a Lab systems Multiskan RC 96-well plate reader (Lab Systems Multiscan RC, Thermo Lab Systems, Franklin, MA, USA). To quantify the growth of the cells, the experimental absorbance values (Aexp) were compared with initial absorbance readings representing the starting cell numbers $\left(\mathrm{A}^{\mathrm{ini}}\right)$. To determine the starting cell number, an additional 96-well plate was seeded with cells and fixed at the beginning of the experiment. The absorbances derived from the initial plate and from the untreated cells at the end of the growth period $\left(\mathrm{A}^{\mathrm{fin}}\right)$ were defined as $0 \%$ and $100 \%$ growth, respectively. The percentage control growth $\left(100 \% \times\left[\mathrm{A}^{\exp }-\mathrm{A}^{\mathrm{ini}}\right] /\left[\mathrm{A}^{\mathrm{fin}}-\mathrm{A}^{\mathrm{ini}}\right]\right)$ is expressed as a percentage of untreated controls.

In vivo experiments. The Institutional Animal Care and Use Committee at the Cleveland Clinic Foundation approved all procedures for animal experimentation (IACUC approval 2017- 
1863). Mice were housed in the Biological Resources Unit in a HEPA air-filtered rack in cages with microisolator tops at a maximum density of five mice per cage. Mice had ad libitum access to standard chow and water (via automatic cage watering system) and kept in a temperature and humidity-controlled environment with a 12 h:12 h light dark cycle. Mice were observed once daily by BRU personnel and once daily by research personnel. Five-weekold NCR male athymic nude homozygous (nu/nu) mice (Taconic, Germantown, NY, USA) were inoculated with A375 tumors. There were four experimental groups (untreated, single agents, and the combination) $n=8$. Cultured tumor cells $\left(4 \times 10^{6}\right)$ were inoculated into flanks in the mid-axillary line. $\mathrm{NO}-\mathrm{Cbl}$ was given twice daily $(50 \mathrm{mg} / \mathrm{kg}$ s.c.) and recombinant trimeric Apo2L/TRAIL ( $50 \mathrm{mg} / \mathrm{kg}$ s.c.) (43) was administered every other day, starting on day 2 . Tumor volume was measured three times a week using the formula for a prolate spheroid: $(4 / 3) \pi a b^{2}$ where $2 a=$ major axis, $2 b=$ minor axis. Mice were euthanized when tumors reached experimental endpoint (maximum $17 \mathrm{~mm}$ diameter), or if there was statistical difference in tumor size between experimental groups, or if mice exhibited $>15 \%$ weight loss, or if mice exhibited lethargy, loss of limb function, vocalization, or other generalized signs of distress. Mice were euthanized using controlled gradient delivery of $\mathrm{CO}_{2}$, followed by cervical dislocation. Formalin-fixed sections were processed by the Cleveland Clinic Histology Core. Sections were stained with hematoxylin and eosin and evaluated for pathologic changes in a blinded fashion.

TUNEL assay. A375 cells were cultured for $36 \mathrm{~h}$ and exposed to various treatments (control, NO-Cbl, Apo2L/TRAIL and NO-Cbl + Apo2L/TRAIL). Apoptotic cells were detected by TUNEL (terminal deoxynucleotidyltransferase-mediated dUTP-biotin nick endlabeling) staining using a commercially available kit (APO BRDU kit, BD-Pharmingen, San Diego, CA, USA). Cells were processed according to the manufacturer's recommended protocol. The percentage of FITC-positive cells was analyzed by fluorescent activated cell scanning (FACS, Becton Dickinson, FACSVantage, San Diego, CA, USA).

Gel electrophoresis and immunoblot analyses. Whole-cell lysates were prepared in $1 \mathrm{x}$ lysis buffer $(50 \mathrm{mM}$ Tris-Cl, $\mathrm{pH} 8.0,1 \%$ Triton $\mathrm{X} 100,10 \%$ glycerol, $1 \mathrm{mM}$ EDTA, $250 \mathrm{mM} \mathrm{NaCl}, 1 \mathrm{mM}$ DTT, 1 $\mathrm{mM}$ PMSF, $10 \mu \mathrm{g} / \mathrm{ml}$ aprotinin, $10 \mu \mathrm{g} / \mathrm{ml}$ leupeptin, and $10 \mu \mathrm{g} / \mathrm{ml}$ pepstatin) for subsequent immunoblotting studies. SDS-PAGE was conducted by using the Laemmli buffer system and $12 \%$ polyacrylamide gels. Proteins were transferred onto PVDF membranes by the semidry method (Trans Blot SD, BioRad, Hercules, CA, USA). Membranes were immunoblotted with, pIkB $\alpha$ and IkB $\alpha$ (Cell Signaling, Beverly, MA, USA), anti-IKK $\alpha / \beta$ (Santa Cruz Biotechnology, Santa Cruz, CA, USA) followed by incubation with HRP-conjugated secondary antibodies (Pierce, Rockford, IL, USA). Immunoreactive bands were visualized by using enhanced chemiluminescence (Perkin Elmer, Waltham MA, USA). Equal protein loading was confirmed by re-probing with monoclonal antiactin antibody (Sigma Chemicals Co, St. Louis, MO, USA).

Dual luciferase $\mathrm{NF}-\mathrm{kB}$ reporter assay. The NF-kB-luciferase (NF-kBluc) reporter plasmid, containing a $2 \times \mathrm{NF}-\mathrm{kB}$ response element fused to luciferase, has been previously characterized (45). Renilla luciferase (pRL-TK, Promega, Madison, WI, USA) was co-transfected to normalize for transfection efficiency. A375 cells were co-transfected with $20 \mu \mathrm{g}$ NF-kB-luc and $10 \mu \mathrm{g}$ pRL-TK using Lipofectamine plus (Gibco BRL/Life Technologies, Invitrogen). After transfection cells recovered overnight and were plated in 6 well plates. Cells were pretreated with NO-Cbl $(100 \mu \mathrm{M})$ for $16 \mathrm{~h}$ followed by TNF- $\alpha(10 \mathrm{ng} / \mathrm{ml})$ or Apo2L/TRAIL ( $100 \mathrm{ng} / \mathrm{ml}$ ) for $4 \mathrm{~h}$. Cells were then harvested in $1 \times$ passive lysis buffer and luciferase activity was measured according to the manufacturer's protocol (Promega,) using a Wallac 1420 multilabel counter (Perkin Elmer). Fold induction of NF-kB-luciferase for each treatment was based on untreated values normalized to the fold induction of pRL-TK reporter values.

IkB kinase (IKK) assay. Whole-cell extracts $(300 \mu \mathrm{g})$ were supplemented with 150 ul of Buffer A (20 mM Hepes, pH 7.9, $20 \mathrm{mM}$ beta-glycerophosphate, $10 \mathrm{mM} \mathrm{NaF}, 0.1 \mathrm{mM}$ orthovanadate, $5 \mathrm{mM}$ para-nitrophenyl phosphate (pNPP), $10 \mathrm{mM}$ 2-mercaptoethanol (BME), $0.5 \mathrm{mM}$ PMSF, and protease cocktail), $2 \mu \mathrm{l}$ normal rabbit serum (NRS), and mixed by rotation at $4^{\circ} \mathrm{C}$ for $1 \mathrm{~h}$ as previously described (46). A $50 \%$ slurry of Protein G Sepharose $(80 \mu \mathrm{l})$ (Amersham-Pharmacia, Piscataway, NJ, USA) prepared in Buffer A (without BME or PMSF) was added and mixed by rotation at $4^{\circ} \mathrm{C}$ for $1 \mathrm{~h}$. Protein $\mathrm{G}$ Sepharose was removed by centrifugation at $800 \times g$ for 1 min and discarded. Anti-IKK $\alpha$ monoclonal antibody $(0.5 \mu \mathrm{g}$, BD-Pharmingen, San Diego, CA, USA), or anti- $\beta$-actin epitope antibody was added to the supernatant and mixed by rotation at $4^{\circ} \mathrm{C}$ for $2 \mathrm{~h}$. A $50 \%$ slurry of Protein G Sepharose $(60 \mu \mathrm{l})$ prepared in Buffer C (Buffer A plus 50 $\mathrm{mM} \mathrm{NaCl}$ and $10 \mathrm{mM} \mathrm{MgCl}_{2}$, without BME and PMSF) was added and mixed by rotation in the cold for $30 \mathrm{~min}$. Protein $\mathrm{G}$ immunopellets were collected by centrifugation at $800 \mathrm{x}$ g for $30 \mathrm{sec}$, washed 3 times with Buffer B (Buffer A plus $250 \mathrm{mM} \mathrm{NaCl}$ ), and once with Buffer C (Buffer A plus $50 \mathrm{mM} \mathrm{NaCl}$ and $10 \mathrm{mM} \mathrm{MgCl}$ ). Immunopellets were re-suspended in $30 \mu \mathrm{l}$ kinase buffer with $0.1 \mathrm{mM}$ orthovanadate, $50 \mu \mathrm{M}$ unlabeled ATP, $5 \mu \mathrm{Ci} \gamma 32 \mathrm{P}-\mathrm{ATP}, 2 \mathrm{mM}$ DTT, and $2 \mu \mathrm{g}$ of recombinant GST-IkB $\alpha 1-54$ (47) and incubated at $30^{\circ} \mathrm{C}$ for $30 \mathrm{~min}$. Reactions were stopped by the addition of $15 \mu \mathrm{l}$ x SDS-PAGE loading buffer (200 mM Tris- $\mathrm{HCl}, \mathrm{pH}$ 6.8, 8\% SDS, 40\% glycerol, $0.2 \% 2-$ mercaptoethanol), heated at $95^{\circ} \mathrm{C}$ for $10 \mathrm{~min}$, and resolved by SDSPAGE on a $12 \%$ acrylamide gel by standard procedures. Gels were rinsed, stained with Bio-Safe Coomassie (BioRad) to visualize protein bands, rinsed, photographed then dried and exposed to Kodak XOMAT AR film (Eastman Kodak Co., Rochester, NY, USA) to detect substrate phosphorylation. IKK activation was quantified by PhosphorImage analysis on a Storm-840 imager using Image Quant v 4.2 software (Molecular Dynamics, Amersham Biosciences).

Statistical analysis. Median effect analysis was used to characterize the interaction between NO-Cbl and Apo2L/TRAIL (48). A combination index $(\mathrm{CI})>1$ indicates antagonism, $\mathrm{CI}=1$ indicates additivity, and $\mathrm{CI}<1$ indicates synergy. Differences in mean tumor volume between groups were compared using the unpaired twotailed Student's $t$-test, using a pooled estimator of variance to determine statistical significance.

\section{Results}

Anti-tumor effects of NO-Cbl, Apo2L/TRAIL, and their combination in vitro and in vivo. To test our hypothesis that NO-Cbl would enhance the anti-cellular effects of Apo2L/TRAIL against malignant Apo2L/TRAIL-resistant cell lines, we measured the antiproliferative effects of three 

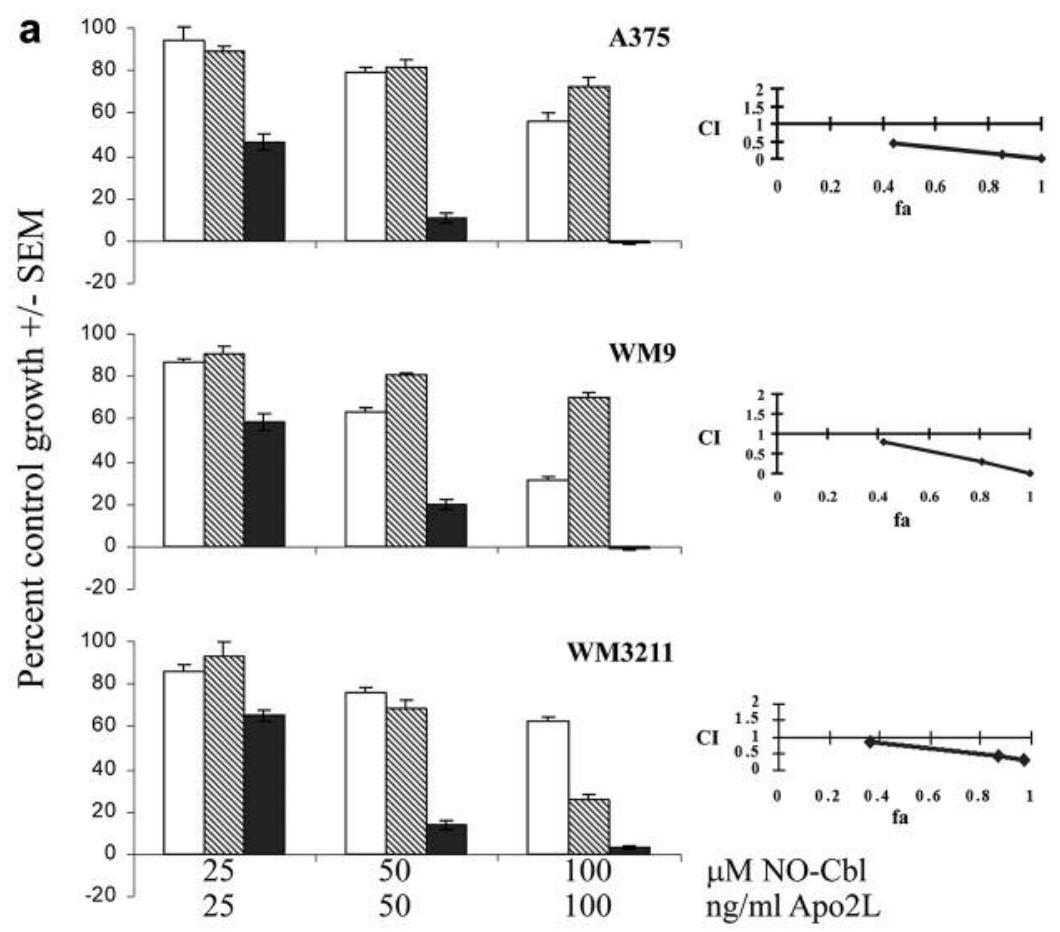

$\mu \mathrm{M} \mathrm{NO}-\mathrm{Cbl}$

$\mathrm{ng} / \mathrm{ml}$ Apo2L

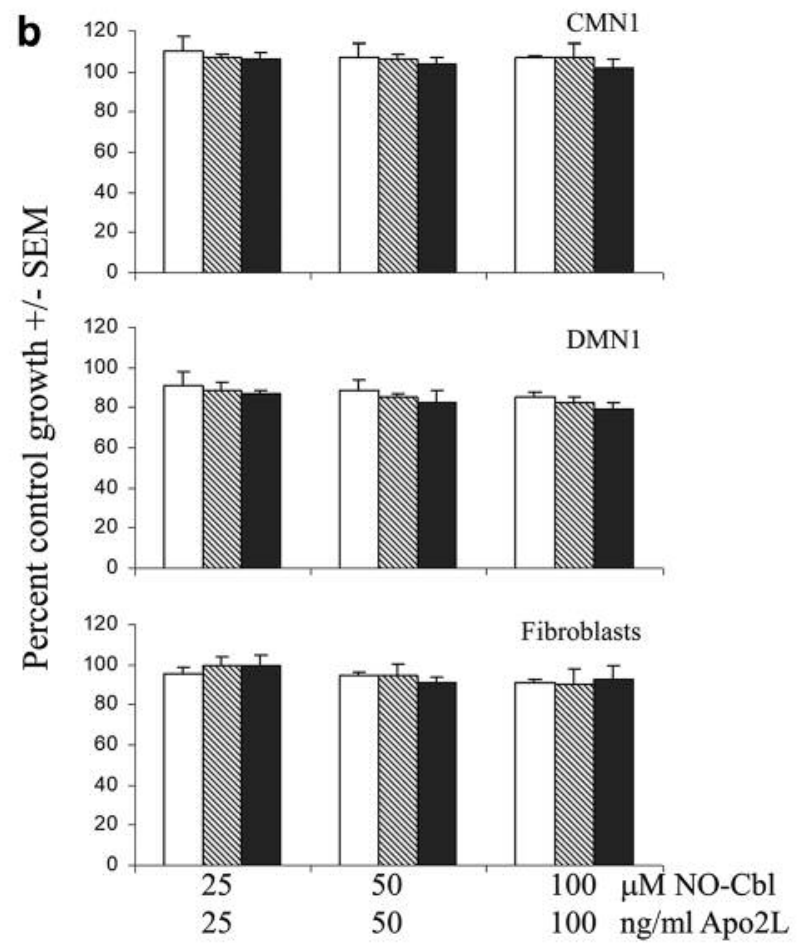

Figure 1. Effects of nitrosylcobalamin (NO-Cbl), Apo2L/TRAIL, and their combination on the proliferation of melanoma cell lines A375, WM9, and WM3211 and normal cell lines CMN1, DMN1, and primary HFF fibroblasts. Left panels: Cells were treated with NO-Cbl (open bars), Apo2L/TRAIL (hatched bars), or pre-treated with NO-Cbl followed by Apo2L/TRAIL (solid bars) for three days, and growth was measured by the colorimetric sulforhodamine B assay (44). Data points represent the mean of four replicates \pm standard error of the mean (SEM). Right panels: Synergy between NO-Cbl and Apo2L/TRAIL was determined by median effect analysis (48), (combination index $>1$ indicates antagonism, =1 indicates additivity, and $<1$ indicates synergy). (a) The sequential treatment of NO-Cbl and Apo2L/TRAIL induced synergistic antiproliferative activity in A375, WM9 and WM3211 cells at each combined dose. (b) Normal melanocyte CMN1 and DMN1 cell lines, and normal HFF fibroblasts were completely resistant to simultaneous exposure to NO-Cbl, Apo2L/TRAIL, or the pre-treatment with NO-Cbl followed by Apo2L/TRAIL. 


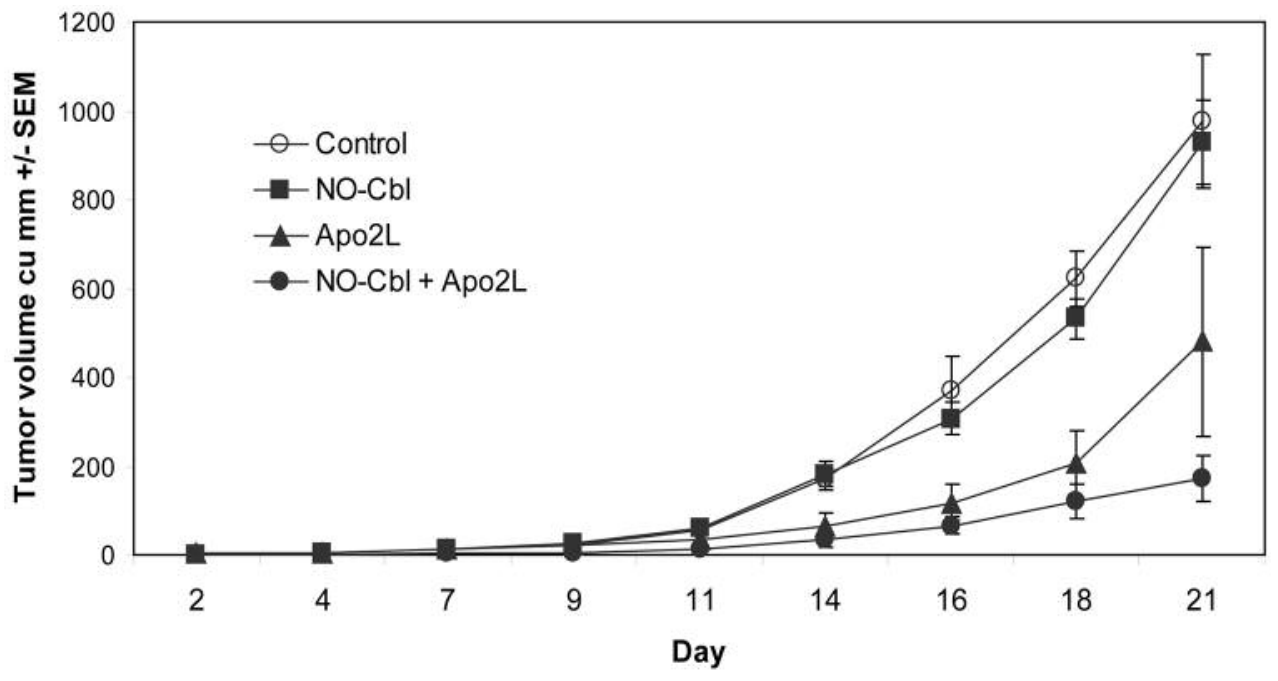

Figure 2. Effect of NO-Cbl, Apo2L/TRAIL and the combination on the growth of A375 melanoma xenografts. NCR male athymic nude (nu/nu) mice were injected subcutaneously with $4 \times 10^{6}$ A375 cells ( $n=8$ per group). Drug treatments began on day 2 after injection of tumor cells. NO-Cbl was administered twice daily for the duration of the study. Apo2L/TRAIL was administered every other day. Control mice received phosphate buffered saline. Tumor volume was measured three times per week. Data points represent the mean tumor volume $\left(\mathrm{mm}^{3}\right) \pm S E M$.

melanoma lines A375, WM9, and WM3211. Three nonmalignant human cell lines CMN1 and DMN1 (normal melanocytes) and primary human foreskin fibroblasts (HFF) were examined to demonstrate the tumor-specific effects of NO-Cbl and Apo2L/TRAIL. We used the SRB antiproliferative assay, used by the National Cancer Institute (NCI) to evaluate new chemotherapeutic agents (44). Median effect analysis was used to characterize the interaction between $\mathrm{NO}-\mathrm{Cbl}$ and Apo2L/TRAIL (48). Cells were pre-treated with NO-Cbl for $16 \mathrm{~h}$ followed by Apo2L/TRAIL for $24 \mathrm{~h}$. Sequential drug treatment resulted in synergistic antiproliferative activity in all three malignant cell lines (Figure 1a). Non-malignant cells were resistant to the antiproliferative effects of NO-Cbl, Apo2L/TRAIL and their combination (Figure 1b). This is consistent with the tumor-specific properties of both $\mathrm{NO}-\mathrm{Cbl}$ and Apo2L/TRAIL $(28,43)$.

To test drug activity in vivo, subcutaneous A375 xenografts were established in nude mice. Daily drug treatments began on day 2 following implantation, at which time tumors were both visible and palpable (Figure 2). After 21 days, the tumors from mice treated with single-agent NOCbl or Apo2L/TRAIL were not significantly smaller than controls. However, the tumors from mice treated with the combination of NO-Cbl and Apo2L/TRAIL were $82.42 \%$ smaller than control tumors $(\mathrm{p} \leq 0.00016)$. The mice maintained their weight and activity and exhibited no adverse side-effects due to single agents or their combination. Compared to the in vitro activity of Apo2L/TRAIL, the enhanced anti-tumor activity observed in vivo likely results from multiple biological effects. In addition, our group confirmed (unpublished data) that Apo2L/TRAIL upregulates NK activity in vivo resulting in synergistic anti-tumor effects (49). Though athymic nude mice lack T-cells, they possess robust NK cell activity.

Mechanism of NO-Cbl/Apo2L/TRAIL-initiated apoptosis. We performed TUNEL assays of A375 cells treated in vitro with NO-Cbl, Apo2L/TRAIL, or their combination. Treatment with NO-Cbl $(100 \mu \mathrm{M})$ or Apo2L/TRAIL (100 $\mathrm{ng} / \mathrm{ml})$ for 36 $\mathrm{h}$ induced $6.2 \%$ and $5.4 \%$ TUNEL-positive cells, respectively (Figure 3). The simultaneous co-treatment of A375 cells with NO-Cbl $(100 \mu \mathrm{M})$ and Apo2L/TRAIL (100 ng/ml) for $36 \mathrm{~h}$ resulted in $28.2 \%$ TUNEL-positive cells. However, sequential pre-treatment of A375 cells with NO-Cbl (100 $\mu \mathrm{M})$ for $12 \mathrm{~h}$, followed by Apo2L/TRAIL (100 ng/ml) for an additional 24 $\mathrm{h}$ induced 98.4\% TUNEL-positive cells, suggesting that NOCbl primes cells to Apo2L/TRAIL-induced apoptosis. In contrast, pre-treatment with Apo2L/TRAIL followed by NOCbl did not enhance TUNEL staining.

Transient transfection assays were performed to assess NF-kB transcriptional activity. A375 cells were cotransfected with a NF-kB-luciferase reporter (NF-kB-luc) and Renilla luciferase (to assess transfection efficiency). Cells were pre-treated with NO-Cbl $(100 \mu \mathrm{M})$ for $16 \mathrm{~h}$ followed by treatment with Apo2L/TRAIL (100 ng/ml) or TNF- $\alpha(10 \mathrm{ng} / \mathrm{ml})$ for $4 \mathrm{~h}$. NO-Cbl pre-treatment caused a $34 \%$ and $51 \%$ inhibition of $\mathrm{NF}-\mathrm{kB}$ activity in response to Apo2L/TRAIL and TNF- $\alpha$, respectively (Figure 4).

We next determined whether NO-Cbl treatment could affect the degradation of $\mathrm{IkB} \alpha$, the prototypic inhibitor of NF-kB (50). 

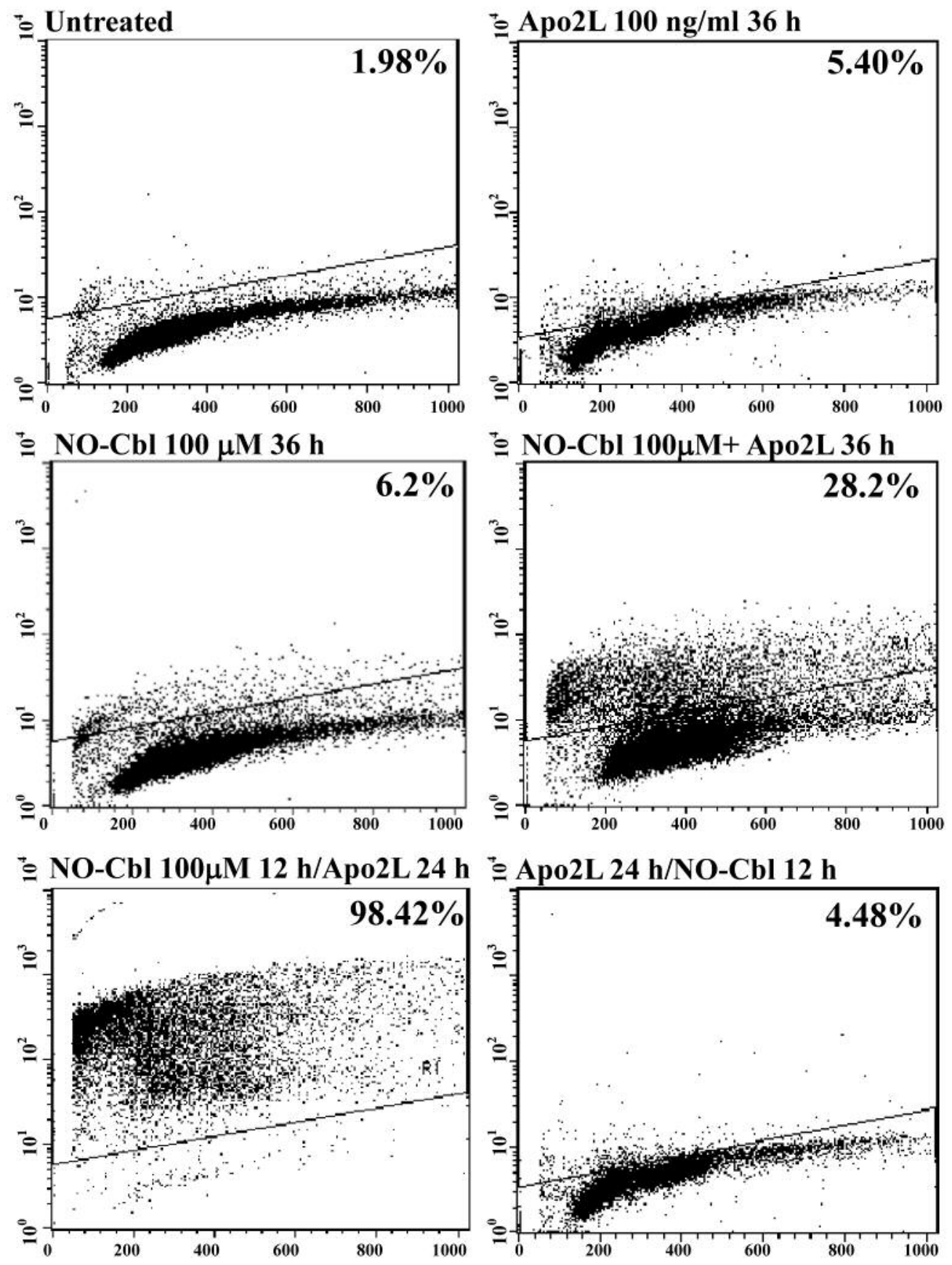

Figure 3. TUNEL apoptosis assay. A375 cells were treated with NO-Cbl, Apo2L/TRAIL, and their combination. NO-Cbl and Apo2L/TRAIL were minimally effective as single agents but demonstrated greater apoptosis when administered concomitantly. The highest levels of apoptosis were observed when cells were pre-treated with NO-Cbl for $12 \mathrm{~h}$ followed by Apo2L/TRAIL treatment for $24 \mathrm{~h}$. Conversely, the effect of Apo2L/TRAIL followed by NO-Cbl was no different than Apo2L/TRAIL alone.

After $15 \mathrm{~min}$ stimulation with $\mathrm{TNF}-\alpha(20 \mathrm{ng} / \mathrm{ml})$ or Apo2L/TRAIL (100 ng/ml, $30 \mathrm{~min})$, IkB $\alpha$ was almost completely degraded (Figure 5a). However, NO-Cbl pretreatment for $16 \mathrm{~h}(100 \mu \mathrm{M})$ completely blocked $\operatorname{IkB} \alpha$ degradation following stimulation with Apo2L/TRAIL. NO-Cbl was much less efficient at blocking $\mathrm{IkB} \alpha$ degradation following TNF- $\alpha$ stimulation. Pre-treatment with NO-Cbl for $16 \mathrm{~h}(100$ $\mu \mathrm{M})$ completely blocked IkB $\alpha$ phosphorylation induced by $1 \mathrm{~h}$ 


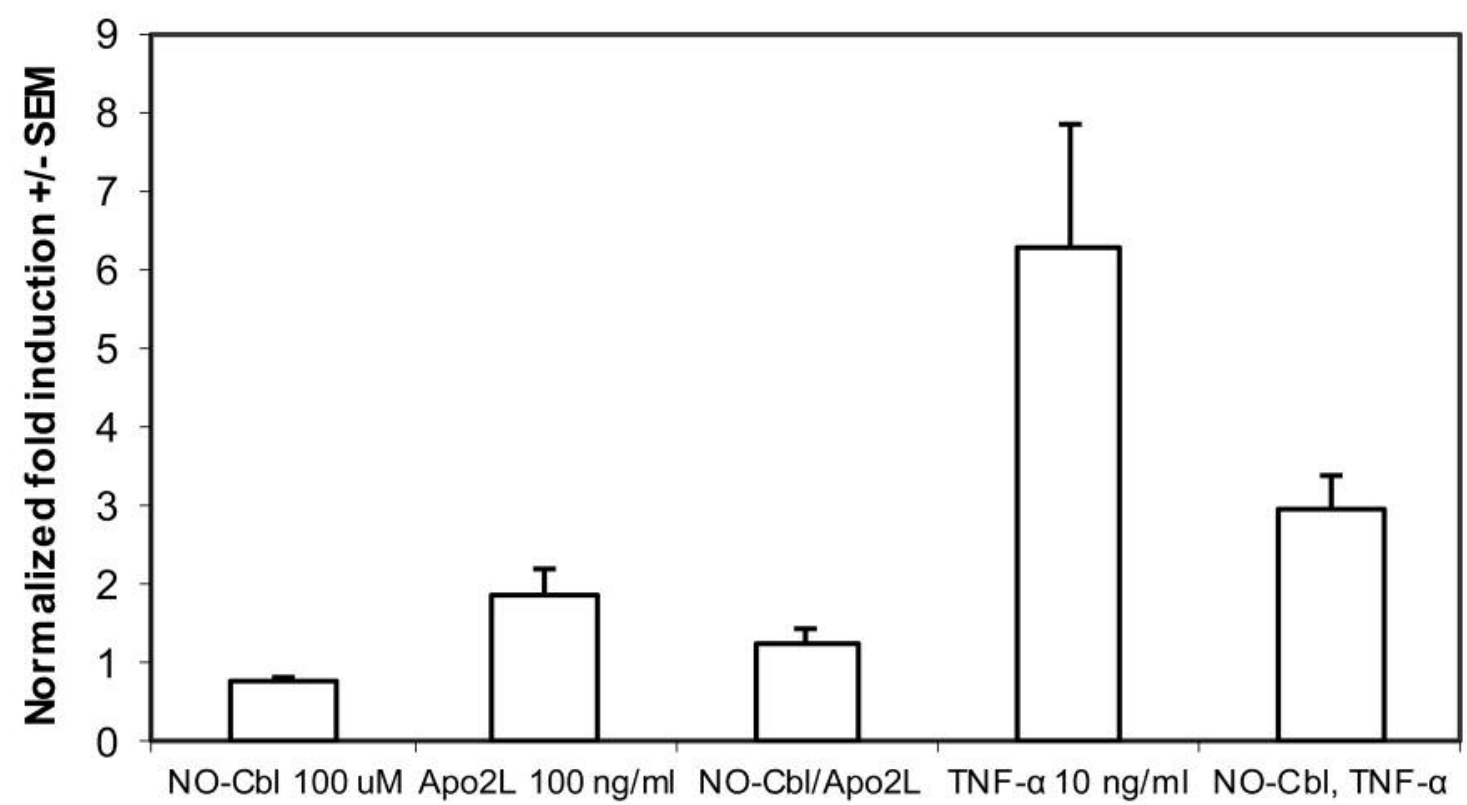

Figure 4. NF-kB-luc reporter assay. NF-KB-luc transfected A375 cells were pre-treated with NO-Cbl for 1 h followed by Apo2L/TRAIL or TNF- $\alpha$ for $4 \mathrm{~h}$. Renilla luciferase was co-transfected to normalize samples for transfection efficiency. Cell lysates were analyzed for $N F-k B$-luc reporter activity. NO-Cbl pre-treatment inhibited Apo2L/TRAIL-and TNF- $\alpha$-induced activation of the NF-kB-luc reporter.

stimulation using Apo2L/TRAIL (100 ng/ml) and decreased that induced by TNF- $\alpha(20 \mathrm{ng} / \mathrm{ml})$ (Figure $5 \mathrm{~b})$. At $1 \mathrm{~h}$ following TNF- $\alpha$ stimulation, IKK remains activated, albeit at reduced levels compared to 15 min (47). Phosphorylation of $\mathrm{IKB} \alpha$ (all of which has been newly synthesized by $1 \mathrm{~h}$ ) is evident. After $1 \mathrm{~h}$, total $\mathrm{IkB} \alpha$ levels were comparable between treatment groups. Accordingly, phospho-IкB $\alpha$ migrates slower than IkB $\alpha$ (Figure 5 b, compare lanes 3 and 4 to other lanes).

Inactivation of $\mathrm{IkB}$ kinase activity by $\mathrm{NO}-\mathrm{Cbl}$. IkB kinase (IKK) is responsible for phosphorylation and activation of IKB $\alpha$, we therefore examined the effect of $\mathrm{NO}-\mathrm{Cbl}$ upon IKK activity. A375 cells were pre-treated with NO-Cbl (100 $\mu \mathrm{M})$ for $16 \mathrm{~h}$ followed by stimulation with Apo2L/TRAIL $(100 \mathrm{ng} / \mathrm{ml})$ or TNF- $\alpha(20 \mathrm{ng} / \mathrm{ml})$ and whole-cell extracts were prepared at $30 \mathrm{~min}$ and $15 \mathrm{~min}$ after treatment, respectively. IKK $\alpha$ was immunoprecipitated from A375 whole-cell extracts and IKK activity was assessed using recombinant GST-IKB $\alpha$ as a substrate (47). NO-Cbl effectively inhibited IKK activity induced by TNF- $\alpha$ and Apo2L/TRAIL by $22 \%$ and $92 \%$, respectively (Figure 6a). Anti- $\beta$-actin antibody was used as an irrelevant antibody control for immunoprecipitation and yielded no signal. The kinase assay gel was stained with Coomassie blue to visualize total protein and demonstrated equal loading of the substrate, GST-IkB $\alpha$ (Figure 6b). The same cell extracts were probed for total IKK by immunoblot analysis and demonstrated equal loading of IKK (Figure 6c).

\section{Discussion}

Induction of apoptosis by exogenous Apo2L/TRAIL requires effective activation of the Apo2L/TRAIL receptors and downstream signaling components. Apo2L/TRAIL, as well as the TRAIL-R1 and TRAIL-R2 receptors are ubiquitously expressed in malignant cells. In the current study, we demonstrated the anti-tumor activity of NO-Cbl as mediated in part by nitric oxide-induced inhibition of $\mathrm{NF}-\mathrm{kB}$ activation. Specifically, we showed that NO-Cbl inhibited IKK enzymatic activity, preventing phosphorylation of IKB in response to Apo2L/TRAIL.

Studies conducted in the early 1990s demonstrated that nitric-oxide donor compounds effectively inhibited NF-kBmediated survival signaling (51) which has been confirmed by recent studies that have established the role of nitric oxide as an inhibitor of NF-kB (52). In addition, a current strategy to enhance TRAIL-mediated cell death is to sensitize TRAIL-resistant tumors by inhibiting TRAIL-mediated survival pathways (53) this is especially important with the clinical use of anti-TRAIL receptor antibodies which has been plagued by TRAIL resistance $(54,55)$.

Researchers have shown that activation of NF-kB is mediated through activation of IKK (56). Remarkably, in our study, NOCbl was more effective at inhibiting Apo2L/TRAIL-induced IKK activity compared to activation by TNF- $\alpha$ which may suggest strong vs. weak activators of IKK. We hypothesize that NO-Cbl may nitrosylate and deactivate a component of the 
A

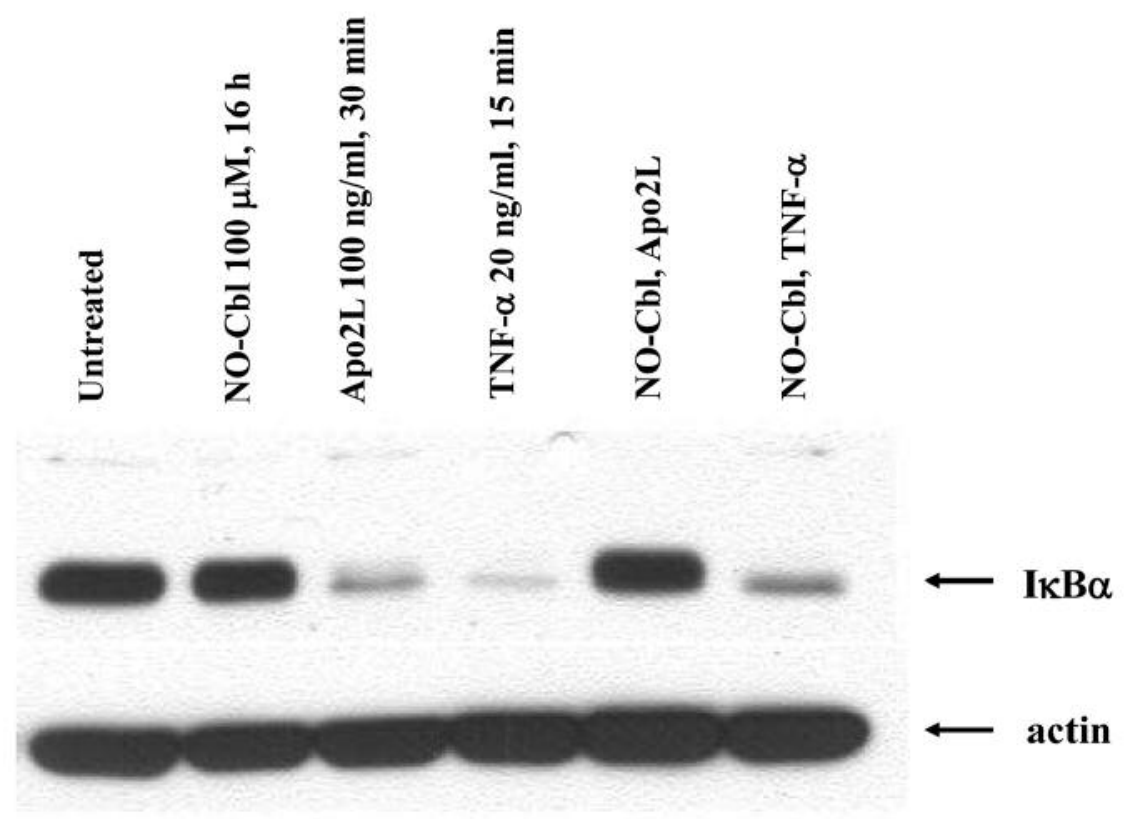

B
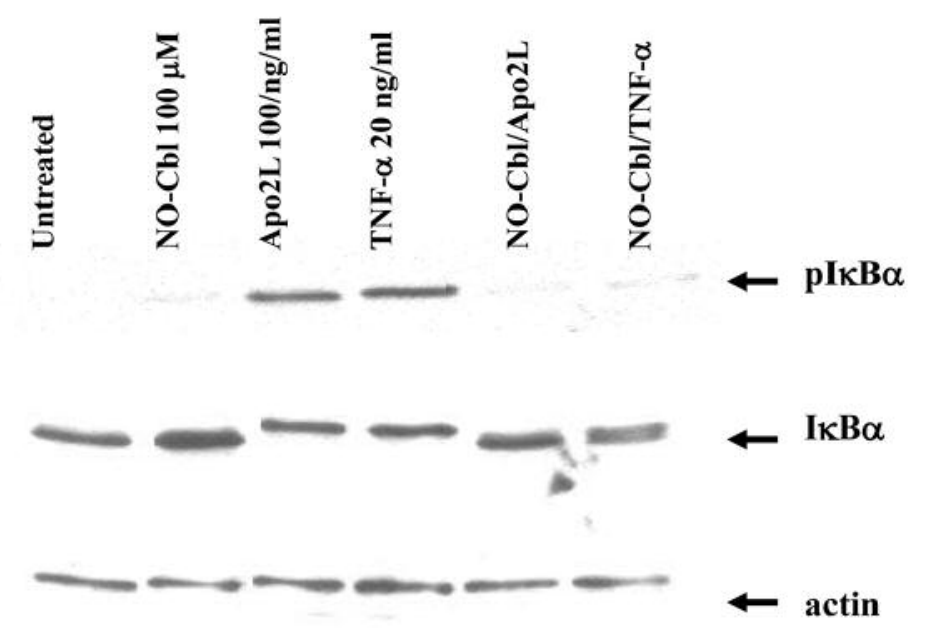

C

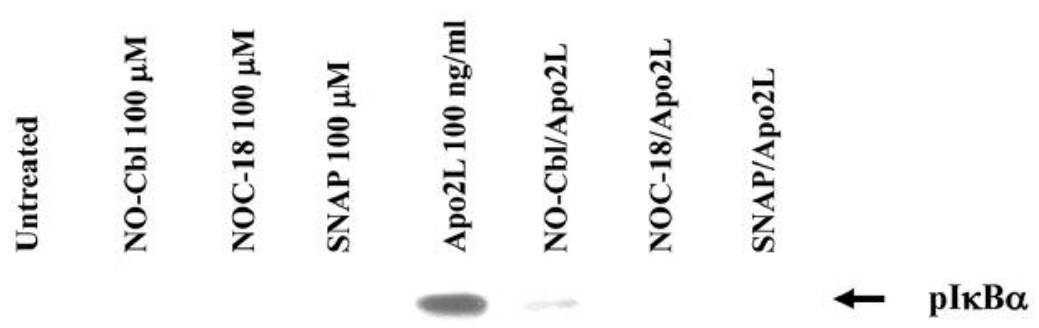

Figure 5. Western blot analysis of IkB $\alpha$ and phospho-IkBa. A375 cells were pre-treated for $16 \mathrm{~h}$ with NO-Cbl followed by Apo2L/TRAIL or TNF- $\alpha$ stimulation. IkB $\alpha$ and phospho-IKB $\alpha$ protein levels were determined in A375 whole-cell lysates. (a) After stimulation with Apo2L/TRAIL (30 min) or TNF- $\alpha$ (15 min), IkB $\alpha$ was almost totally degraded. NO-Cbl efficiently blocked IkB $\alpha$ degradation following Apo2L/TRAIL, but only partially blocked $I k B \alpha$ degradation following $T N F-\alpha .(b)$ After $1 \mathrm{~h}$, cellular levels of $I \mathrm{k} B \alpha$ are restored as a result of re-synthesis. NO-Cbl blocks the phosphorylation of

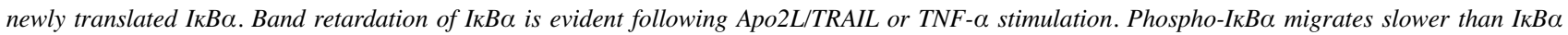
(compare middle two lanes to other four lanes). c, NO-Cbl, NOC-18, and SNAP pre-treatment all inhibited Apo2L/TRAIL-induced IkB $\alpha$ phosphorylation. 
A

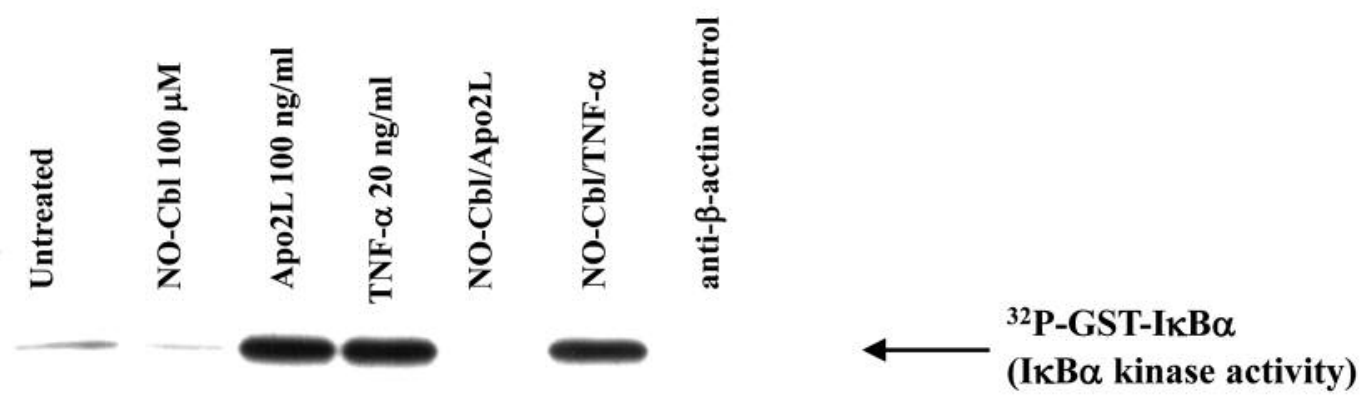

B

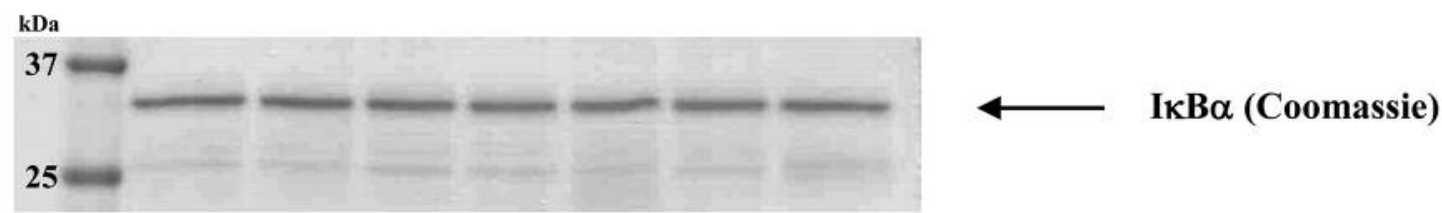

C
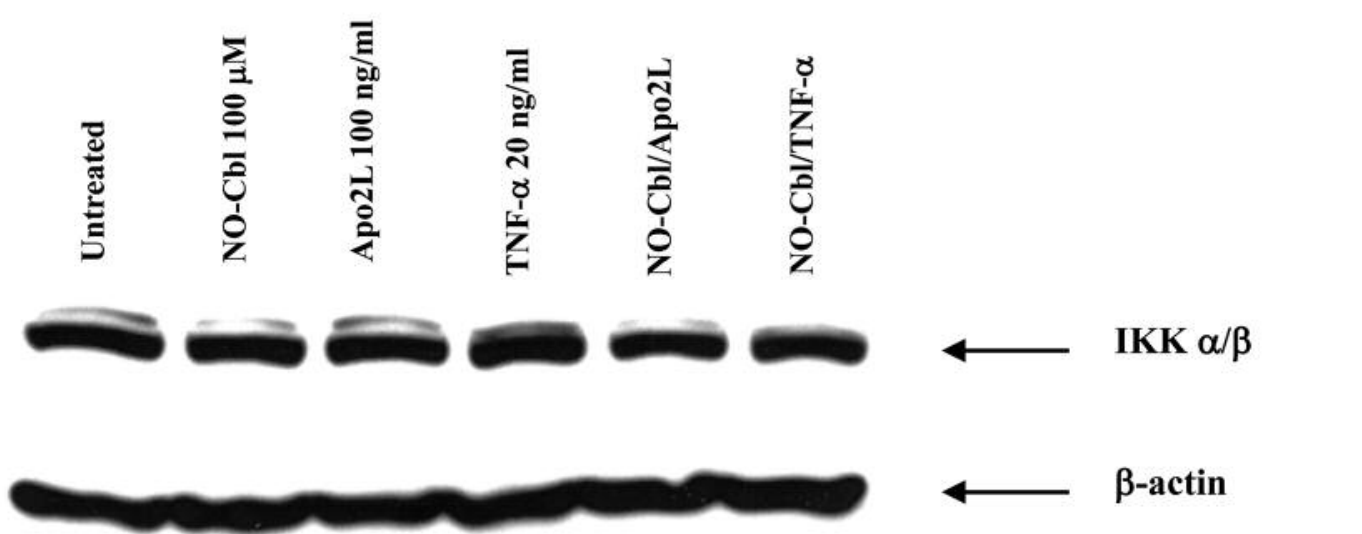

Figure 6. IKB kinase (IKK) activity. IKK activity was assessed using recombinant GST-IKB $\alpha(1-54)$ and $\gamma 32 P$-ATP as substrates. The phosphorylated GST fusion protein was detected by autoradiography. (a) IKK activity was determined in A375 cells pre-treated with NO-Cbl followed by Apo2L/TRAIL or TNF- $\alpha$ stimulation for $30 \mathrm{~min}$ and $15 \mathrm{~min}$, respectively. NO-Cbl treatment inhibited IKK activity more effectively when Apo2L/TRAIL was the stimulus, compared to stimulation by TNF- $\alpha$. Anti- $\beta$-actin antibody served as the irrelevant antibody with no phosphorylation

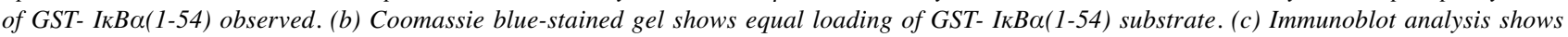
the presence of equal amounts of total IKK in the lysates. $\beta$-actin was used as a loading control.

Apo2L/TRAIL pathway that is absent from the TNF- $\alpha$ pathway. This functional divergence is under active investigation.

Similarly, others have shown that NO can inhibit NF-kB by nitrosylating critical cysteine residues (57-59). Interestingly, prostaglandins (PGA1 and 15dPGJ2) can inhibit IKK by covalently modifying a critical cysteine residue $(\mathrm{C} 179)$ within the activation loop (60). In a similar manner, NO-Cbl may inhibit IKK, or an IKK-related kinase which is critical for Apo2L/TRAIL signaling but is less important for TNF- $\alpha$ signaling.

A major advantage of the pro-drug NO-Cbl is its tumorspecific accumulation (28). Cobalamin (Cbl) is avidly taken up by tumor cells relative to most normal tissues (61-63). Unlike other nitric oxide donors, NO-Cbl releases NO inside the cell (28), and therefore minimizes systemic toxicity. NO$\mathrm{Cbl}$ is relatively tumor-specific due to transcobalamin receptor (TCII-R; CD320)-mediated uptake and intercellular transport by TCII, which are overexpressed in cancer compared to normal tissues $(29,30)$.

Chemoresistance is a major problem for multi-cycle chemotherapy and involves multiple pathways and molecular factors $(64,65)$ which has resulted in the use of immunotherapies and combination treatments (65). NF-kB plays a major role in survival signaling and is a promising 
target to potentiate the anti-tumor effects of chemotherapy and radiotherapy as demonstrated in several review articles (66-73). Currently, several clinical trials evaluating or involving NF-kB are recruiting patients in the cancer setting (74). The use of NO to inhibit NF- $\mathrm{KB}$ activation is a favorable strategy as the use of NO is becoming more readily available clinically $(75,76)$.

\section{Conclusion}

The use of NO-Cbl to deliver intra-tumor NO and inhibit survival signaling represents a promising approach to antitumor therapy to help mitigate TRAIL resistance. Our study provides the rationale for the use of $\mathrm{NO}$, generated by nitric oxide donors, nitric oxide synthase activators, and NOprecursors with the goal of potentiating anticancer therapies. However, further studies are required to determine the exact mechanism of action by which NO inhibits NF-kB. Our study demonstrates the potential of nitric oxide in the multimodal treatment of cancer and highlights the need to develop NF$\mathrm{kB}$-pathway inhibitors which merits future exploration especially in the context of TRAIL cancer treatments.

\section{Conflicts of Interest}

JAB is employed by Nitric Oxide Services, LLC. No competing interests for DJL, JAD, or JAL.

\section{Authors' Contributions}

JAB, DJL, JAD: Conceived and designed the analysis; JAB, JAL: Performed the analysis; JAB, DJL, JAD: Wrote and edited the paper.

\section{Acknowledgements}

This study was supported by the American Cancer Society (JAB), Ethicon Endosurgery (JAB), CCF Innovations (JAB), and the Taussig Cancer Center Bridge Grant Program (DJL). This study was included as part of the dissertation of (JAL) and was included in the U.S. Patent Application Publication 20080138280 (JAB).

\section{References}

1 Reed JC: Apoptosis-targeted therapies for cancer. Cancer Cell 3(1): 17-22, 2003. PMID: 12559172. DOI: 10.1016/s15356108(02)00241-6

2 Wiley SR, Schooley K, Smolak PJ, Din WS, Huang CP, Nicholl JK, Sutherland GR, Smith TD, Rauch C and Smith CA: Identification and characterization of a new member of the tnf family that induces apoptosis. Immunity 3(6): 673-682, 1995. PMID: 8777713. DOI: 10.1016/1074-7613(95)90057-8

3 Pitti RM, Marsters SA, Ruppert S, Donahue CJ, Moore A and Ashkenazi A: Induction of apoptosis by apo-2 ligand, a new member of the tumor necrosis factor cytokine family. J Bioll Chem 271(22): 12687-12690, 1996. PMID: 8663110. DOI: $10.1074 /$ jbc.271.22.12687
4 Walczak H, Miller RE, Ariail K, Gliniak B, Griffith TS, Kubin M, Chin W, Jones J, Woodward A, Le T, Smith C, Smolak P, Goodwin RG, Rauch CT, Schuh JC and Lynch DH: Tumoricidal activity of tumor necrosis factor-related apoptosis-inducing ligand in vivo. Nat Med 5(2): 157-163, 1999. PMID: 9930862. DOI: $10.1038 / 5517$

5 Ashkenazi A: Targeting death and decoy receptors of the tumour-necrosis factor superfamily. Nat Rev Cancer 2(6): 420430, 2002. PMID: 12189384. DOI: $10.1038 / \mathrm{nrc} 821$

6 Ashkenazi A, Pai RC, Fong S, Leung S, Lawrence DA, Marsters SA, Blackie C, Chang L, McMurtrey AE, Hebert A, DeForge L, Koumenis IL, Lewis D, Harris L, Bussiere J, Koeppen H, Shahrokh Z and Schwall RH: Safety and antitumor activity of recombinant soluble apo2 ligand. J Clin Invest 104(2): 155-162, 1999. PMID: 10411544. DOI: 10.1172/JCI6926

7 Frese S, Brunner T, Gugger M, Uduehi A and Schmid RA: Enhancement of apo21/trail (tumor necrosis factor-related apoptosis-inducing ligand)-induced apoptosis in non-small cell lung cancer cell lines by chemotherapeutic agents without correlation to the expression level of cellular protease caspase8 inhibitory protein. J Thorac Cardiovasc 123(1): 168-174, 2002. PMID: 11782771. DOI: $10.1067 / \mathrm{mtc} .2002 .119694$

8 Gliniak B and Le T: Tumor necrosis factor-related apoptosisinducing ligand's antitumor activity in vivo is enhanced by the chemotherapeutic agent cpt-11. Cancer Res 59(24): 6153-6158, 1999. PMID: 10626806.

9 Mizutani Y, Nakanishi H, Yoshida O, Fukushima M, Bonavida $\mathrm{B}$ and Miki T: Potentiation of the sensitivity of renal cell carcinoma cells to trail-mediated apoptosis by subtoxic concentrations of 5-fluorouracil. Eur J Cancer 38(1): 167-176, 2002. PMID: 11750847. DOI: 10.1016/s0959-8049(01)00339-2

10 Yamanaka T, Shiraki K, Sugimoto K, Ito T, Fujikawa K, Ito M, Takase K, Moriyama M, Nakano $T$ and Suzuki A: Chemotherapeutic agents augment trail-induced apoptosis in human hepatocellular carcinoma cell lines. Hepatology 32(3): 482-490, 2000. PMID: 10960439. DOI: 10.1053/jhep.2000.16266

11 Chinnaiyan AM, Prasad U, Shankar S, Hamstra DA, Shanaiah M, Chenevert TL, Ross BD and Rehemtulla A: Combined effect of tumor necrosis factor-related apoptosis-inducing ligand and ionizing radiation in breast cancer therapy. PNAS 97(4): 17541759, 2000. PMID: 10677530. DOI: 10.1073/pnas.030545097

12 Kim MR, Lee JY, Park MT, Chun YJ, Jang YJ, Kang CM, Kim $\mathrm{HS}$, Cho CK, Lee YS, Jeong HY and Lee SJ: Ionizing radiation can overcome resistance to trail in trail-resistant cancer cells. FEBS Lett 505(1): 179-184, 2001. PMID: 11557065. DOI: 10.1016/s0014-5793(01)02816-2

13 Di Pietro R, Secchiero P, Rana R, Gibellini D, Visani G, Bemis $\mathrm{K}$, Zamai L, Miscia $\mathrm{S}$ and Zauli G: Ionizing radiation sensitizes erythroleukemic cells but not normal erythroblasts to tumor necrosis factor-related apoptosis-inducing ligand (trail) mediated cytotoxicity by selective up-regulation of trail-r1. Blood 97(9): 2596-2603, 2001. PMID: 11313247. DOI: 10.1182/blood.v97.9.2596

14 Willms A, Schittek H, Rahn S, Sosna J, Mert U, Adam D and Trauzold A: Impact of p53 status on trail-mediated apoptotic and non-apoptotic signaling in cancer cells. PLoS One 14(4): e0214847, 2019. PMID: 30947287. DOI: 10.1371/journal.pone.0214847

15 Walczak H, Bouchon A, Stahl $\mathrm{H}$ and Krammer PH: Tumor necrosis factor-related apoptosis-inducing ligand retains its apoptosis-inducing capacity on bcl-2- or bcl-xl-overexpressing 
chemotherapy-resistant tumor cells. Cancer Res 60(11): 30513057, 2000. PMID: 10850456.

16 Wong SHM, Kong WY, Fang CM, Loh HS, Chuah LH, Abdullah S and Ngai SC: The trail to cancer therapy: Hindrances and potential solutions. Crit Rev Oncol Hematol 143: 81-94, 2019. PMID: 31561055. DOI: 10.1016/j.critrevonc.2019.08.008

17 Saini S, Sripada L, Tulla K, Qiao G, Kunda N, Maker AV and Prabhakar BS: Madd silencing enhances anti-tumor activity of trail in anaplastic thyroid cancer. Endocr Relat Cancer 26(6): 551-563, 2019. PMID: 30999276. DOI: 10.1530/erc-18-0517

18 Piggott L, Silva A, Robinson T, Santiago-Gómez A, Simões BM, Becker M, Fichtner I, Andera L, Young P, Morris C, Barrett-Lee P, Alchami F, Piva M, Vivanco MD, Clarke RB, Gee J and Clarkson R: Acquired resistance of er-positive breast cancer to endocrine treatment confers an adaptive sensitivity to trail through posttranslational downregulation of c-flip. Clin Cancer Res 24(10): 2452-2463, 2018. PMID: 29363524. DOI: 10.1158/1078-0432.ccr-17-1381

19 Oikonomou E and Pintzas A: The trail of oncogenes to apoptosis. Biofactors 39(4): 343-354, 2013. PMID: 23813857. DOI: 10.1002/biof.1112

20 Saraei R, Soleimani M, Movassaghpour Akbari AA, Farshdousti Hagh M, Hassanzadeh A and Solali S: The role of xiap in resistance to tnf-related apoptosis-inducing ligand (trail) in leukemia. Biomed Pharmacother 107: 1010-1019, 2018. PMID: 30257312. DOI: 10.1016/j.biopha.2018.08.065

21 Mahalingam D, Szegezdi E, Keane M, de Jong S and Samali A: Trail receptor signalling and modulation: Are we on the right trail? Cancer Treat Rev 35(3): 280-288, 2009. PMID: 19117685. DOI: 10.1016/j.ctrv.2008.11.006

22 Hussain SP, Trivers GE, Hofseth LJ, He P, Shaikh I, Mechanic LE, Doja S, Jiang W, Subleski J, Shorts L, Haines D, Laubach VE, Wiltrout RH, Djurickovic D and Harris CC: Nitric oxide, a mediator of inflammation, suppresses tumorigenesis. Cancer Res 64(19): 6849-6853, 2004. PMID: 15466171. DOI: 10.1158/00085472.CAN-04-2201

23 Kamm A, Przychodzen P, Kuban-Jankowska A, Jacewicz D, Dabrowska AM, Nussberger S, Wozniak $M$ and GorskaPonikowska M: Nitric oxide and its derivatives in the cancer battlefield. Nitric Oxide 93: 102-114, 2019. PMID: 31541733 DOI: 10.1016/j.niox.2019.09.005

24 Huerta S: Nitric oxide for cancer therapy. Future Sci OA 1(1): Fso44, 2015. PMID: 28031862. DOI: 10.4155/fso.15.44

25 Morbidelli L: Therapeutic potential of nitric oxide donors in cancer: Focus on angiogenesis. Crit Rev Oncog 21(5-6): 447-458, 2016. PMID: 29431088. DOI: 10.1615/CritRevOncog.2017021114

26 Huerta S, Chilka S and Bonavida B: Nitric oxide donors: Novel cancer therapeutics (review). Int J Oncol 33(5): 909-927, 2008. PMID: 18949354.

27 Reynolds MM, Witzeling SD, Damodaran VB, Medeiros TN, Knodle RD, Edwards MA, Lookian PP and Brown MA: Applications for nitric oxide in halting proliferation of tumor cells. Biochem Biophys Res Commun 431(4): 647-651, 2013. PMID: 23337501. DOI: 10.1016/j.bbrc.2013.01.041

28 Bauer JA, Morrison BH, Grane RW, Jacobs BS, Dabney S, Gamero AM, Carnevale KA, Smith DJ, Drazba J, Seetharam B and Lindner DJ: Effects of interferon beta on transcobalamin ii-receptor expression and antitumor activity of nitrosylcobalamin. J Natl Cancer Inst 94(13): 1010-1019, 2002. PMID: 12096086. DOI: 10.1093/jnci/94.13.1010
29 Sysel AM, Valli VE and Bauer JA: Immunohistochemical quantification of the cobalamin transport protein, cell surface receptor and ki-67 in naturally occurring canine and feline malignant tumors and in adjacent normal tissues. Oncotarget 6(4): 2331-2348, 2015. PMID: 25633912. DOI: 10.18632/oncotarget.3206

30 Sysel AM, Valli VE, Nagle RB and Bauer JA: Immunohistochemical quantification of the vitamin $\mathrm{b} 12$ transport protein (tcii), cell surface receptor (tcii-r) and ki-67 in human tumor xenografts. Anticancer Res 33(10): 4203-4212, 2013. PMID: 24122983.

31 Tang Z, Bauer JA, Morrison B and Lindner DJ: Nitrosylcobalamin promotes cell death via s nitrosylation of apo21/trail receptor $\mathrm{dr} 4$. Mol Cell Biol 26(15): 5588-5594, 2006. PMID: 16847314. DOI: 10.1128/MCB.00199-06

32 Yang J, LeBlanc FR, Dighe SA, Hamele CE, Olson TL, Feith DJ and Loughran TP, Jr.: Trail mediates and sustains constitutive nf-kb activation in lgl leukemia. Blood 131(25): 2803-2815, 2018. PMID: 29699990. DOI: 10.1182/blood-2017-09-808816

33 Zhang L, Dittmer MR, Blackwell K, Workman LM, Hostager B and Habelhah H: Trail activates jnk and nf-kb through rip1dependent and -independent pathways. Cell Signal 27(2): 306314, 2015. PMID: 25446254. DOI: 10.1016/j.cellsig.2014.11.014

34 MacFarlane M: Trail-induced signalling and apoptosis. Toxicol Lett 139(2-3): 89-97, 2003. PMID: 12628743. DOI: 10.1016/ s0378-4274(02)00422-8

35 Liu PC, Lu G, Deng Y, Wang CD, Su XW, Zhou JY, Chan TM, $\mathrm{Hu} \mathrm{X}$ and Poon WS: Inhibition of nf-kb pathway and modulation of mapk signaling pathways in glioblastoma and implications for lovastatin and tumor necrosis factor-related apoptosis inducing ligand (trail) combination therapy. PLoS One 12(1): e0171157, 2017. PMID: 28135339. DOI: 10.1371/journal.pone. 0171157

36 Sancilio S, Di Giacomo V, Quaglietta AM, Iacone A, Angelucci D, Tatasciore U, Rana RA, Cataldi A, Zauli G and Di Pietro R: Trail promotes a pro-survival signal in erythropoietin-deprived human erythroblasts through the activation of an nf-kb/ikbalpha pathway. J Biol Regul Homeost Agents 25(3): 375-386, 2011. PMID: 22023762.

37 Bauer JA, Lupica JA, Schmidt H, Morrison BH, Haney RM, Masci RK, Lee RM, Didonato JA and Lindner DJ: Nitrosylcobalamin potentiates the anti-neoplastic effects of chemotherapeutic agents via suppression of survival signaling. PLoS One 2(12): e1313, 2007. PMID: 18074035. DOI: 10.1371/journal.pone.0001313

38 Guo Q, Liu Y, Zhao J, Wang J, Li Y, Pang Y, Chen J and Wang $\mathrm{J}$ : Evodiamine inactivates $\mathrm{nf}-\mathrm{kb}$ and potentiates the antitumor effects of gemcitabine on tongue cancer both in vitro and in vivo. Onco Targets Ther 12: 257-267, 2019. PMID: 30643424. DOI: $10.2147 /$ ott.s181062

39 Gupta SC, Sundaram C, Reuter S and Aggarwal BB: Inhibiting $\mathrm{nf}-\mathrm{kb}$ activation by small molecules as a therapeutic strategy. Biochim Biophys Acta 1799(10-12): 775-787, 2010. PMID: 20493977. DOI: 10.1016/j.bbagrm.2010.05.004

40 Lee JY, Huerta-Yepez S, Vega M, Baritaki S, Spandidos DA and Bonavida B: The no trail to yes trail in cancer therapy (review). Int J Oncol 31(4): 685-691, 2007. PMID: 17786298.

41 Huerta-Yepez S, Vega M, Jazirehi A, Garban H, Hongo F, Cheng $\mathrm{G}$ and Bonavida B: Nitric oxide sensitizes prostate carcinoma cell lines to trail-mediated apoptosis via inactivation of nf-kappa $\mathrm{b}$ and inhibition of bcl-xl expression. Oncogene 23(29): 49935003, 2004. PMID: 15048072. DOI: 10.1038/sj.onc.1207655 
42 Bauer JA: Synthesis, characterization and nitric oxide release profile of nitrosylcobalamin: A potential chemotherapeutic agent. Anticancer Drugs 9(3): 239-244, 1998. PMID: 9625434. DOI: 10.1097/00001813-199803000-00006

43 Lawrence D, Shahrokh Z, Marsters S, Achilles K, Shih D, Mounho B, Hillan K, Totpal K, DeForge L, Schow P, Hooley J, Sherwood S, Pai R, Leung S, Khan L, Gliniak B, Bussiere J, Smith CA, Strom SS, Kelley S, Fox JA, Thomas D and Ashkenazi A: Differential hepatocyte toxicity of recombinant apo21/trail versions. Nat Med 7(4): 383-385, 2001. PMID: 11283636. DOI: $10.1038 / 86397$

44 Skehan P, Storeng R, Scudiero D, Monks A, McMahon J, Vistica D, Warren JT, Bokesch H, Kenney S and Boyd MR: New colorimetric cytotoxicity assay for anticancer-drug screening. J Natl Cancer Inst 82(13): 1107-1112, 1990. PMID: 2359136. DOI: $10.1093 /$ jnci/82.13.1107

45 Elewaut D, DiDonato JA, Kim JM, Truong F, Eckmann L and Kagnoff MF: Nf-kappa $b$ is a central regulator of the intestinal epithelial cell innate immune response induced by infection with enteroinvasive bacteria. J Immunol 163(3): 1457-1466, 1999. PMID: 10415047.

46 DiDonato JA: Assaying for i kappa b kinase activity. Methods Enzymol 322: 393-400, 2000. PMID: 10914035. DOI: 10.1016/s0076-6879(00)22038-7

47 DiDonato JA, Hayakawa M, Rothwarf DM, Zandi E and Karin M: A cytokine-responsive ikappab kinase that activates the transcription factor nf-kappab. Nature 388(6642): 548-554, 1997. PMID: 9252186 . DOI: $10.1038 / 41493$

48 Chou TC and Talalay P: Quantitative analysis of dose-effect relationships: The combined effects of multiple drugs or enzyme inhibitors. Adv Enzym Regul 22: 27-55, 1984. PMID: 6382953. DOI: $10.1016 / 0065-2571(84) 90007-4$

49 Sato K, Hida S, Takayanagi H, Yokochi T, Kayagaki N, Takeda $\mathrm{K}$, Yagita H, Okumura K, Tanaka N, Taniguchi T and Ogasawara $\mathrm{K}$ : Antiviral response by natural killer cells through trail gene induction by ifn-alpha/beta. Eur J Immunol 31(11): 3138-3146, 2001. PMID: 11745330. DOI: 10.1002/1521-4141(200111) 31:11<3138::aid-immu3138>3.0.co;2-b

50 DiDonato JA, Mercurio F and Karin M: Phosphorylation of i kappa $\mathrm{b}$ alpha precedes but is not sufficient for its dissociation from nf-kappa b. Mol Cell Biology 15(3): 1302-1311, 1995. PMID: 7862124. DOI: $10.1128 / \mathrm{mcb} .15 .3 .1302$

51 Matthews JR, Botting CH, Panico M, Morris HR and Hay RT: Inhibition of nf-kappab DNA binding by nitric oxide. Nucleic Acids Res 24(12): 2236-2242, 1996. PMID: 8710491. DOI: $10.1093 /$ nar/24.12.2236

52 Taylor EL, Megson IL, Haslett C and Rossi AG: Nitric oxide: A key regulator of myeloid inflammatory cell apoptosis. Cell Death Differ 10(4): 418-430, 2003. PMID: 12719719. DOI: 10.1038/sj.cdd.4401152

53 Wang S: The promise of cancer therapeutics targeting the tnfrelated apoptosis-inducing ligand and trail receptor pathway. Oncogene 27(48): 6207-6215, 2008. PMID: 18931688. DOI: $10.1038 /$ onc. 2008.298

54 Deng D and Shah K: Trail of hope meeting resistance in cancer. Trends Cancer, 2020. PMID: 32718904. DOI: 10.1016/ j.trecan.2020.06.006

55 Stuckey DW and Shah K: Trail on trial: Preclinical advances in cancer therapy. Trends Mol Med 19(11): 685-694, 2013. PMID: 24076237. DOI: 10.1016/j.molmed.2013.08.007
56 Adli M, Merkhofer E, Cogswell P and Baldwin AS: Ikkalpha and ikkbeta each function to regulate nf-kappab activation in the tnf-induced/canonical pathway. PLoS One 5(2): e9428, 2010. PMID: 20195534. DOI: 10.1371/journal.pone. 0009428

57 DelaTorre A, Schroeder RA and Kuo PC: Alteration of nf-kappa b p50 DNA binding kinetics by s-nitrosylation. Biochem Biophys Res Commun 238(3): 703-706, 1997. PMID: 9325152. DOI: $10.1006 /$ bbrc.1997.7279

58 Matthews JR, Botting CH, Panico M, Morris HR and Hay RT: Inhibition of nf-kappab DNA binding by nitric oxide. Nucleic Acids Res 24(12): 2236-2242, 1996. PMID: 8710491. DOI: $10.1093 / \mathrm{nar} / 24.12 .2236$

59 Marshall HE and Stamler JS: Inhibition of nf-kappa b by snitrosylation. Biochemistry 40(6): 1688-1693, 2001. PMID: 11327828. DOI: 10.1021/bi002239y

60 Rossi A, Kapahi P, Natoli G, Takahashi T, Chen Y, Karin M and Santoro MG: Anti-inflammatory cyclopentenone prostaglandins are direct inhibitors of ikappab kinase. Nature 403(6765): 103108, 2000. PMID: 10638762. DOI: 10.1038/47520

61 Flodh $\mathrm{H}$ and Ullberg S: Accumulation of labelled vitamin b12 in some transplanted tumours. Int J Cancer 3(5): 694-699, 1968. PMID: 5724527. DOI: 10.1002/ijc.2910030518

62 Cooperman JM, Luhby AL, Teller DN and Marley JF: Distribution of radioactive and nonradioactive vitamin b12 in the dog. J Biol Chem 235(1): 191-194, 1960. PMID: 13811818.

63 Collins DA, Hogenkamp HP, O'Connor MK, Naylor S, Benson LM, Hardyman TJ and Thorson LM: Biodistribution of radiolabeled adenosylcobalamin in patients diagnosed with various malignancies. Mayo Clin Proc 75(6): 568-580, 2000. PMID: 10852417. DOI: 10.4065/75.6.568

64 Zheng HC: The molecular mechanisms of chemoresistance in cancers. Oncotarget 8(35): 59950-59964, 2017. PMID: 28938696. DOI: 10.18632 /oncotarget.19048

65 Barbari C, Fontaine T, Parajuli P, Lamichhane N, Jakubski S, Lamichhane $\mathrm{P}$ and Deshmukh RR: Immunotherapies and combination strategies for immuno-oncology. Int $\mathrm{J}$ Mol Sci 21(14), 2020. PMID: 32679922. DOI: 10.3390/ijms21145009

66 Godwin P, Baird AM, Heavey S, Barr MP, O'Byrne KJ and Gately K: Targeting nuclear factor-kappa $b$ to overcome resistance to chemotherapy. Front Oncol 3: 120, 2013. PMID: 23720710. DOI: $10.3389 /$ fonc 2013.00120

67 Nakanishi C and Toi M: Nuclear factor-kappab inhibitors as sensitizers to anticancer drugs. Nat Rev Cancer 5(4): 297-309, 2005. PMID: 15803156 . DOI: $10.1038 / \mathrm{nrc} 1588$

$68 \mathrm{Li} \mathrm{F}$ and Sethi G: Targeting transcription factor nf-kappab to overcome chemoresistance and radioresistance in cancer therapy. Biochim Biophys Acta 1805(2): 167-180, 2010. PMID: 20079806. DOI: 10.1016/j.bbcan.2010.01.002

69 Liu YC, Chiang IT, Hsu FT and Hwang JJ: Using nf-kb as a molecular target for theranostics in radiation oncology research. Expert Rev Mol Diagn 12(2): 139-146, 2012. PMID: 22369374. DOI: $10.1586 /$ erm.12.2

70 Li Q, Yang G, Feng M, Zheng S, Cao Z, Qiu J, You L, Zheng $\mathrm{L}, \mathrm{Hu} \mathrm{Y}, \mathrm{Zhang} \mathrm{T}$ and Zhao Y: Nf-kb in pancreatic cancer: Its key role in chemoresistance. Cancer Lett 421: 127-134, 2018. PMID: 29432846. DOI: 10.1016/j.canlet.2018.02.011

71 Durand JK and Baldwin AS: Targeting ikk and nf-kb for therapy. Adv Protein Chem Struct Biol 107: 77-115, 2017. PMID: 28215229. DOI: $10.1016 /$ bs.apcsb.2016.11.006 
72 Kim HJ, Hawke N and Baldwin AS: Nf-kappab and ikk as therapeutic targets in cancer. Cell Death Differ 13(5): 738-747, 2006. PMID: 16485028. DOI: 10.1038/sj.cdd.4401877

73 Verzella D, Pescatore A, Capece D, Vecchiotti D, Ursini MV, Franzoso G, Alesse E and Zazzeroni F: Life, death, and autophagy in cancer: Nf-kb turns up everywhere. Cell Death Dis 11(3): 210, 2020. PMID: 32231206. DOI: 10.1038/s41419-0202399-y

74 Labbozzetta M, Notarbartolo $\mathrm{M}$ and Poma P: Can nf-kb be considered a valid drug target in neoplastic diseases? Our point of view. Int J Mol Sci 21(9), 2020. PMID: 32349210. DOI: 10.3390/ijms21093070

75 Dowell JC, Thomas NJ and Yehya N: Association of response to inhaled nitric oxide and duration of mechanical ventilation in pediatric acute respiratory distress syndrome. Pediatr Crit Care Med 18(11): 1019-1026, 2017. PMID: 29099443. DOI: 10.1097/pcc.0000000000001305

76 Parikh R, Wilson C, Weinberg J, Gavin D, Murphy J and Reardon CC: Inhaled nitric oxide treatment in spontaneously breathing covid-19 patients. Ther Adv Respir Dis 14, 2020. PMID: 32539647. DOI: 10.1177/1753466620933510

Received September 11, 2020

Revised October 20, 2020

Accepted October 27, 2020 